development as a bioassay tool for morphological and physiological investigations at the molecular level of the cuticula of small nematodes.

Although swarming bears superficial resemblance to anabiosis ${ }^{*}, 5$, the following points indicate the two phenomena differ fundamentally in origin and nature. Swarming is characterized by: (a) an innate morphological modification of the cuticle in nonswarmers, which probably originates during its secretion by the hypodermis; (b) an active physiological state induced by favourable environmental conditions; $(c)$ participation of all stages of worm development; $(d)$ the breadth 'heiterkeit' of nematode forms encompassed, including the Dorylaimoidea.

This evidence is suggestive of a hypothesis that swarming and anabiosis represent the bipolar extremes of a hypothotical (perhaps real) series of physiological states between activity and dormancy. Work has boen interrupted for one year, beginning September 1961. Present emphasis is being placed on the investigation of taxonomic aspects of species specificity and possible relations betwoen physiological states and pathogenicity.

Department of Plant Pathology,

$$
\text { JoHN P. HoLLIS * }
$$

Louisiana State University,

Baton Rouge, Louisiana.

* Present address: Scott Agricultural Laboratory, Nairobi, Kenya. ${ }^{1}$ Hoillis, J. P., Nature, 182, 956 (1958).

${ }^{2}$ Hollis, J. P., Phytopath., 50, 639 (1960).

"Tairbairn, D., Exp. Parasitol., 6, 491 (1957).

- Steiner, G., Proc. Third Intern. Cong. Microbiol., New York, 434 (1940).

${ }^{5}$ Stciner, G., Proc. Fourteenth Intern. Cong. Zool., Copenhagen, 368 (1956).

\section{Territorial Function of Chin Gland Secretion in the Rabbit, Oryctolagus cuniculus (L.)}

InvRstigation of wild rabbits confined in experimental enclosures of approximately 2 acres at Gungahlin, near Canberra, and at Albury has established the existence of discrete social groups, each with its own territory and dominance hierarchy ${ }^{4,5}$. In the enclosure at Gungahlin, rabbits have been observed to mark objects in their territories with the secretion of the chin gland, as well as with urine and freces. Features such as the edges of posts, tips of grass blades and branches, edges of burrow entrances, walls and ceilings of cages, and even kittens and does during amatory behaviour, are subjected to 'chinning' during which they are smeared with small amounts of secretion.

A survey of the literature on the secretory glands under the skin between the rami of the mandible of the rabbit indicated that both the histology and function of this gland complex would repay further investigation. The superficial mandibulary gland, which has been wrongly classified as a salivary gland ${ }^{1-3}$, represents only the antero-lateral portion of the organ. No references have been found to the much larger central glands. Mislawsky's thesis which, according to Buschke1, deals in detail with the superficial mandibulary gland is not available.

The chin gland of the full-grown buck rabbit is always larger than that of the doe of corresponding ago and may weigh ten times as much. The weight is correlated with age. At three months, when sexual maturity is reached, rabbits ean be sexed from the appearance of the chin region. The fur on the ehin of the female is smooth, with only slight traces of secretion from the small glands. In males, the fur is matted with a yellowish incrustation, the large glands can be palpated easily, and drops of colourless secretion can be pressed from the semicircular row of pores. The largest glands are found in the dominant bucks which are mainly responsible for the maintenance and defence of the territory.

The marking behaviour of domestic rabbits has been examined, and it has been found that males mark almost ten times as often as females. Those individuals that marked most frequently in isolation dominated weaker markers when brought into contact with them. Castration reduced the size and activity of the gland, and also inhibited the desire to mark. Implantation of testosterone restored the functioning of the gland in castrates, stimulated its secretion in females, and also increased the urge to mark.

Chin glands were found to bo much less developed in the hare, Lepus europaeus Pallas, which has a much larger home-range than the rabbit. This observation lends support to the view that territorial marking is of value among gregarious species by advertising that the area is at present occupied, thus minimizing aggressive fighting.

A histological study of the chin gland is in progress, in collaboration with Dr. A. G. Lyne, of Ian Clunies Ross Animal Research Laboratory, C.S.I.R.O., Prospect, New South Wales.

Commonwealth Scientific and

\section{R. MYkyTowycz}

Industrial Research Organization, Wildlife Survey Section, Canberra.

${ }^{1}$ Buschke, W., Z. Zellforsch. und mikroskop. Anat., 18, 217 (1933). ${ }^{2}$ Krause, W., Die Anatomie des Kaninchens in topographischer und operativer Rücksicht, second ed. (Engelmann, Leipzig, 1884).

${ }^{3}$ Sohaffer, J., Die Hautdrüsenorgane der Saügetiere (Urban and Schwarzenberg, Berlin and Wien, 1940).

- Myers, K., and Mykytowycz, R., Nature, 181, 1515 (1958).

'Mykytowycz, R., C.S.I.R.O. Wildl. Res., 3, 7 (1958).

\section{Morphology of the Cetacean Reniculus}

A Drstrnctrve feature of cetacean morphology is the disposition of the renal tissue as a conglomeration of anatomically discrete units (renculi, reniculi, renules) to the number of some hundreds or even thousands. Each such reniculus comprises a medullary pyramid, a surrounding cortex and an independent calyx leading by moans of an infundibulum into a ureteric tributary. The renicular blood vessels lie on the calyx and enter the reniculus at the corticomedullary junction.

Attention has been directed ${ }^{x}$ to a hitherto unde. scribed morphological peculiarity of the cetacean reniculus, namely, the presence of an intrarenicular prolongation of the muscle and collagen components of the calyx wall in the form of a basket (sporta perimedullaris musculosa) which surrounds and partially embraces the single medullary pyramid. The intrinsic renicular arteries lie to the outside of this sporta and their branches to the base of the medullary pyramid enter through the interstices thereof. These histological particulars are shown diagrammatically in Fig. 1.

This peculiar histological feature of the cetacean reniculus was first noted in the pigmy right whale (Caperea (Neobalaena) marginata) and thereafter in the sperm whale (Physeter catodon), the common porpoise (Phocaena phocoena) and the crucigerous dolphin (Lagenorhynchus cruciger). 